\title{
Enteric methane, lactation performances, digestibility, and metabolism of nitrogen and energy of Holsteins and Jerseys fed 2 levels of forage fiber from alfalfa silage or corn silage
}

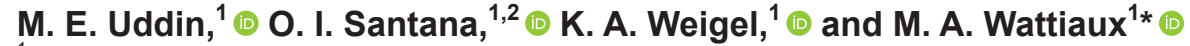 \\ ${ }^{1}$ Department of Dairy Science, University of Wisconsin-Madison, 53706 \\ ${ }^{2}$ Instituto Nacional de Investigaciones Forestales, Agrícolas y Pecuarias (INIFAP), Campo Experimental Pabellón, Pabellón de Arteaga, \\ Aguascalientes, México 20660
}

\begin{abstract}
Our objective was to determine the effects of replacing alfalfa silage (AS) neutral detergent fiber (NDF) with corn silage (CS) NDF at 2 levels of forage NDF (FNDF) on enteric methane $\left(\mathrm{CH}_{4}\right)$, lactation performance, ruminal fluid characteristics, digestibility, and metabolism of $\mathrm{N}$ and energy in Holstein and Jersey cows. Twelve Holstein and 12 Jersey cows (all primiparous and mid-lactation) were used in a triplicated splitplot $4 \times 4$ Latin square experiment, where breed and diet formed the main and subplots, respectively. The 4 iso-nitrogenous and iso-starch dietary treatments were arranged as a $2 \times 2$ factorial with 2 levels of FNDF [19 (low FNDF, LF) and 24\% (high FNDF, HF) of dry matter] and 2 sources of FNDF (70:30 and 30:70 ratio of AS NDF to CS NDF). Soyhull (non-forage NDF) and corn grain were respectively used to keep dietary NDF and starch content similar across diets. Total collection of feces and urine over $3 \mathrm{~d}$ was performed on 8 cows (1 Latin square from each breed). The difference in dry matter intake (DMI) between Holsteins and Jerseys was greater when fed AS than CS. Compared with Jerseys, Holstein cows had greater body weight (48\%), DMI (34\%), fat- and protein-corrected milk (FPCM; $31 \%$ ) and $\mathrm{CH}_{4}$ production $(22 \% ; 471$ vs. 385 $\mathrm{g} / \mathrm{d})$. However, breed did not affect $\mathrm{CH}_{4}$ intensity $(\mathrm{g} / \mathrm{kg}$ of FPCM) or yield ( $\mathrm{g} / \mathrm{kg}$ of DMI), nutrient digestibility, and $\mathrm{N}$ partitioning. Compared with HF, LF-fed cows had greater DMI (10\%), N intake (8\%), and FPCM (5\%), but they were $5 \%$ less efficient (both FPCM/ DMI and milk N/intake N). Compared with HF, LFfed cows excreted 11 and $17 \%$ less urinary $\mathrm{N}(\mathrm{g} / \mathrm{d}$ and $\%$ of $\mathrm{N}$ intake, respectively). In spite of lower (2.5\%) acetate and higher (10\%) propionate (mol/100 mol ruminal volatile fatty acids) LF-fed cows had greater
\end{abstract}

Received September 17, 2019.

Accepted February 25, 2020.

*Corresponding author: wattiaux@wisc.edu
(6\%) $\mathrm{CH}_{4}$ production (g/d) than did HF-fed cows, most likely due to increased DMI, as affected mainly by the soyhulls. Compared with AS, CS-fed cows had greater DMI (7\%) and FPCM (4\%), but they were less efficient $(5 \%)$, and $\mathrm{CH}_{4}$ yield $(\mathrm{g} / \mathrm{kg}$ of DMI) was reduced by $8 \%$. In addition, per unit of gross energy intake, CS-fed cows lost less urinary energy (15\%) and $\mathrm{CH}$ energy (11\%) than did AS-fed cows. We concluded that, in contrast to level and source of FNDF, breed did not affect digestive and metabolic efficiencies, and, furthermore, neither breed nor dietary treatments affected $\mathrm{CH}_{4}$ intensity. The tradeoff between $\mathrm{CH}_{4}$ and $\mathrm{N}$ losses may have implications in future studies assessing the environmental effects of milk production when approached from a whole-farm perspective.

Key words: forage source, feed efficiency, greenhouse gas, nitrogen excretion

\section{INTRODUCTION}

In the United States, milk from the dairy sector contributes approximately $1.9 \%$ of the national greenhouse gas (GHG) inventory (Thoma et al., 2013). Although this contribution to the national inventory is minimal, emphasis has been placed on reducing the milk carbon footprint. Cradle-to-grave life cycle assessment has suggested an average emission of $2.05 \mathrm{~kg}$ of $\mathrm{CO}_{2}$ equivalents per kilogram of fat- and protein-corrected milk (FPCM; Thoma et al., 2013). The same study revealed that the 3 major on-farm GHG sources, namely feed production, enteric methane $\left(\mathrm{CH}_{4}\right)$, and manure management, comprise about $70 \%$ of the recorded emissions, indicating that on-farm mitigation strategies could contribute substantially to reducing the carbon footprint of milk consumed in the United States (Wattiaux et al., 2019).

In the Midwest, increasing herd size without concomitant increase in the land base has progressively led dairy farmers to rely increasingly on corn silage (CS) at the expense of alfalfa silage (AS), which historically has 
been a major component of their feeding and cropping systems. For instance, the proportion of cropland used for CS production in dairy operations has increased $75 \%$ during the 30 years between 1982 and 2012 (Martin et al., 2017). Therefore, it is important to quantify the effects of changing forages in dairy diet on animal performance, efficiency, and the environment (Uddin, 2019). Increasing forage level in the diet by increasing both $\mathrm{AS}$ and $\mathrm{CS}$ in the same ratio increased $\mathrm{CH}_{4}$ production $(\mathrm{g} / \mathrm{d})$, yield $(\mathrm{g} / \mathrm{kg}$ of DMI), and intensity $(\mathrm{g} / \mathrm{kg}$ of FPCM; Aguerre et al., 2011). However, altering the AS:CS ratio at a constant forage level resulted invariably in quadratic $\mathrm{CH}_{4}$ emission responses (Hassanat et al., 2013; Arndt et al., 2015a). However, the varying level of dietary starch in the 3 aforementioned studies may have had confounding effects, leaving unclear the nature of the interaction between level and source of forage NDF (FNDF). Furthermore, greater AS:CS in the diet linearly increased manure $\mathrm{N}$ excretions (Hassanat et al., 2013; Arndt et al. 2015a), which would likely increase nitrous oxide emission during manure storage (Külling et al., 2001) and after field application (Allen et al., 1996).

Breed may also influence undesirable $\mathrm{C}$ and $\mathrm{N}$ losses from dairy cows. Approximately 3 percentage unit greater NDF digestibility for Jersey compared with Holstein cows has been reported by Aikman et al. (2008) and Olijhoek et al. (2018). Furthermore, the latter authors reported a breed $\times$ diet interaction for $\mathrm{CH}_{4}$ yield $(P<0.001)$ and for $\mathrm{CH}_{4}$ intensity $(P=0.10)$, suggesting greater mitigation potential for Holstein than for Jersey cows with increasing levels of concentrates in the diet. Although urinary N (\% of $\mathrm{N}$ intake) did not differ between breed in Aikman et al. (2008) and Kauffman and St-Pierre (2001), the latter authors detected 3.5 and 4.8 percentage units lower $\mathrm{N}$ digestibility and productive $\mathrm{N}[($ milk $\mathrm{N}+$ retained $\mathrm{N}) / \mathrm{N}$ intake $]$, respectively, for Jerseys compared with Holsteins.

This manuscript reports the findings of the first in a series of studies aimed at quantifying GHG emissions not only as enteric $\mathrm{CH}_{4}$ from lactating cows but also from the upstream sources associated with cropping systems (relying primarily on either alfalfa or corn) and the downstream sources associated with the manure management chain (Uddin, 2019). In this study, we posited the existence of interactions influencing $\mathrm{C}$ and $\mathrm{N}$ losses. Specifically, we hypothesized that $\mathrm{CH}_{4}$ and urinary $\mathrm{N}$ losses are influenced differentially by breed in response to dietary changes. Furthermore, we hypothesized that the change in $\mathrm{CH}_{4}$ emission when cows consume low- (LF) versus high-forage fiber diets (HF) depends on whether the primary source of FNDF in the diet is from AS or CS. We intended to explore these effects by varying the level and the source of fiber in balanced diets rather than to determine the specific effect of AS and CS as a forage source. Thus, the objective of this study was to determine the main effects and interactions of diets formulated with 2 levels of FNDF with either AS or CS on enteric $\mathrm{CH}_{4}$, lactation performance, nutrient digestibility, rumen characteristics, and metabolism of $\mathrm{N}$ and energy of Holstein and Jersey cows.

\section{MATERIALS AND METHODS}

The Institutional Animal Care and Use Committee-approved protocol was followed for animal use and care during entire period of the experiment, which was conducted at the Dairy Cattle Center, University of Wisconsin-Madison.

\section{Animals, Design of Experiment, and Dietary Treatments}

Twelve primiparous Holstein [mean $\pm \mathrm{SD} ; 34.5 \mathrm{~kg} / \mathrm{d}$ milk yield (MY), $606 \pm 40 \mathrm{~kg} \mathrm{BW}$, and $106 \pm 17 \mathrm{DIM}]$ and 12 primiparous Jersey $(23.0 \mathrm{~kg} / \mathrm{d}$ MY, $407 \pm 43$ $\mathrm{kg} \mathrm{BW}$, and $112 \pm 15$ DIM) cows housed in a tiestall barn, fed once daily $(0730 \mathrm{~h})$, supplied water ad libitum, and milked twice daily (0430 and 1630h), were included in this experiment. The design was a split-plot $4 \times 4$ Latin square in which breed and diet formed the main and subplots, respectively. Furthermore, we triplicated Latin square in each breed to get enough statistical power to detect treatment differences. Each experimental period lasted $4 \mathrm{wk}$, with sampling conducted in wk 3 and 4 . Cows were fed 4 diets in a $2 \times 2$ factorial arrangement with 2 levels of FNDF (19.0 and 24.0\% of DM) and 2 sources of FNDF (70:30 and 30:70 ratios of AS NDF to CS NDF). Diets were offered as TMR and included LF (19.0\% FNDF) with a 70:30 ratio of AS NDF:CS NDF (LFAS), LF with a 30:70 ratio of AS NDF:CS NDF (LFCS), HF (24.0\% FNDF) with a 70:30 ratio of AS NDF:CS NDF (HFAS), and HF with a 30:70 ratio of AS NDF:CS NDF (HFCS; see Table 1). To achieve similar dietary levels of starch, CP, NDF, and gross energy (GE), as well as NRC-predicted levels of RDP, RUP, and $\mathrm{NE}_{\mathrm{L}}$ (NRC, 2001), diets with greater proportions of AS than CS had greater inclusion of corn grain, less solvent soybean meal, and more expeller soybean, whereas diets with higher proportions of FNDF had lower inclusion of soyhulls (Table 1).

\section{Collection and Analyses of Feed and Milk Samples}

Samples of AS and CS were collected weekly for moisture determination at $60^{\circ} \mathrm{C}$ for $48 \mathrm{~h}$, and TMR were adjusted accordingly at the beginning of each 
Table 1. Ingredients and chemical composition of dietary treatments

\begin{tabular}{|c|c|c|c|c|}
\hline \multirow[b]{2}{*}{ Item } & \multicolumn{4}{|c|}{ Dietary treatment ${ }^{1}$} \\
\hline & LFAS & LFCS & HFAS & HFCS \\
\hline \multicolumn{5}{|l|}{ Ingredient, $\%$ of $\mathrm{DM}$} \\
\hline Forage & 53.6 & 55.3 & 66.9 & 69.1 \\
\hline Alfalfa silage (AS) & 36.6 & 15.7 & 45.7 & 19.6 \\
\hline Corn silage (CS) & 17.0 & 39.6 & 21.2 & 49.5 \\
\hline Corn grain & 22.0 & 9.5 & 20.0 & 4.5 \\
\hline Soybean meal expeller & 4.0 & 1.5 & 5.6 & 2.2 \\
\hline Soybean meal solvent & 3.2 & 10.5 & 0 & 9.5 \\
\hline Soyhulls & 12.7 & 18.7 & 3.0 & 10.2 \\
\hline Blood meal & 0.7 & 0.7 & 0.7 & 0.7 \\
\hline GreenFeed bait mixture ${ }^{2}$ & 2.0 & 2.0 & 2.0 & 2.0 \\
\hline Vitamins and minerals ${ }^{3}$ & 1.75 & 1.75 & 1.75 & 1.75 \\
\hline \multicolumn{5}{|l|}{$\begin{array}{l}\text { Chemical composition, \% of DM } \\
\text { unless stated otherwise }\end{array}$} \\
\hline $\mathrm{OM}$ & 92.1 & 93.0 & 91.7 & 92.9 \\
\hline $\mathrm{CP}$ & 17.3 & 16.9 & 17.2 & 16.7 \\
\hline $\mathrm{RDP}^{4}$ & 11.1 & 10.6 & 11.1 & 10.5 \\
\hline $\mathrm{RUP}^{4}$ & 6.2 & 6.3 & 6.1 & 6.2 \\
\hline $\mathrm{aNDF}^{5}$ & 30.5 & 32.9 & 29.0 & 32.8 \\
\hline Non-forage NDF & 11.3 & 13.7 & 5.0 & 8.8 \\
\hline Forage NDF & 19.2 & 19.2 & 24.0 & 24.0 \\
\hline AS NDF & 13.4 & 5.8 & 16.8 & 7.2 \\
\hline CS NDF & 5.8 & 13.4 & 7.2 & 16.8 \\
\hline AS NDF:CS NDF & $70: 30$ & $30: 70$ & $70: 30$ & $30: 70$ \\
\hline $\mathrm{ADF}$ & 22.5 & 22.5 & 22.0 & 22.8 \\
\hline ADL & 3.2 & 2.4 & 3.7 & 2.8 \\
\hline Hemicellulose ${ }^{6}$ & 8.0 & 10.4 & 7.0 & 10.0 \\
\hline Cellulose $^{7}$ & 19.3 & 20.1 & 18.2 & 20.0 \\
\hline Starch & 22.1 & 22.9 & 23.0 & 22.7 \\
\hline Fat & 2.4 & 2.2 & 2.5 & 2.3 \\
\hline $\mathrm{NFC}^{8}$ & 41.4 & 40.8 & 42.7 & 41.1 \\
\hline Gross energy, Mcal $/ \mathrm{kg}$ of DM & 4.37 & 4.36 & 4.39 & 4.40 \\
\hline $\mathrm{NE}_{\mathrm{L}},{ }^{9} \mathrm{Mcal} / \mathrm{kg}$ of DM & 1.52 & 1.50 & 1.50 & 1.48 \\
\hline
\end{tabular}

${ }^{1}$ LFAS $=$ low-forage $(19.0 \%)$ NDF with a $70: 30$ ratio of alfalfa silage (AS) NDF to corn silage (CS) NDF; LFCS = low-forage $(19.0 \%)$ NDF with a 30:70 ratio of AS NDF to CS NDF; HFAS = high-forage (24.0\%) NDF with a 70:30 ratio of AS NDF to CS NDF; HFCS = high-forage (24.0\%) NDF with a 30:70 ratio of AS NDF to CS NDF.

${ }^{2}$ GreenFeed bait mixture (C-Lock Inc., Rapid City, SD), composed of $60 \%$ corn grain, $10 \%$ soybean meal, and $30 \%$ molasses (DM basis) was added to the TMR except for the days of $\mathrm{CH}_{4}$ measurement, when it was used as bait in the GreenFeed unit.

${ }^{3}$ Vitamins and minerals (DM basis) were composed of $0.5 \%$ monocalcium phosphate (21\% phosphorus), $0.25 \%$ magnesium oxide $(56 \%$ magnesium), $0.25 \%$ sodium bicarbonate ( $27 \%$ sodium), $0.25 \%$ salt (iodized granulated sodium chloride), and $0.5 \%$ lactating trace minerals and vitamins $(87 \mathrm{mg} / \mathrm{kg}$ selenium, 2,014,540 IU $/ \mathrm{kg}$ vitamin A, 402,930 $\mathrm{IU} / \mathrm{kg}$ vitamin $\mathrm{D}_{3}$, and $8,543 \mathrm{IU} / \mathrm{kg}$ vitamin $\left.\mathrm{E}\right)$.

${ }^{4} \mathrm{RDP}$ and RUP calculated using NRC (2001) equation based on formulated diet.

${ }^{5} \mathrm{aNDF}=$ amylase-treated NDF, corrected for ash.

${ }^{6}$ Hemicellulose $=$ NDF - ADF .

${ }^{7}$ Cellulose $=\mathrm{ADF}-\mathrm{ADL}$.

${ }^{8} \mathrm{NFC}=100-(\mathrm{CP}+\mathrm{NDF}+$ fat + ash $)$.

${ }^{9} \mathrm{NE}_{\mathrm{L}}$ calculated using NRC (2001) equation based on actual diet and cow performance data.

week throughout the experiment. Samples of concentrate mixtures ( 1 for each TMR), AS, CS, and bait feed mixture (used for enteric $\mathrm{CH}_{4}$ measurement) were collected daily during each sampling period. Samples were frozen at $-20^{\circ} \mathrm{C}$ until further analysis. All feed samples were dried at $60^{\circ} \mathrm{C}$ for $48 \mathrm{~h}$ in a forced-air oven and ground in a Wiley mill (Arthur H. Thomas, Philadelphia, PA) to pass a 1-mm screen. Each feed sample was then composited by period, and each composited sample was analyzed in duplicates for absolute DM by drying at $100^{\circ} \mathrm{C}$ for $24 \mathrm{~h}$, starch as per Hall (2009), total N via combustion method (Leco FP-2000 N Analyzer, Leco Instruments Inc., St. Joseph, MI), amylasetreated NDF using Ankom (ash-corrected; method 2002.04, AOAC International, 2016), ADF and lignin using Ankom (ash-corrected; method 973.18, AOAC International, 2016), ash at $600^{\circ} \mathrm{C}$ for $2 \mathrm{~h}$ to calculate OM (method 942.05, AOAC International, 2016), crude fat via acid hydrolysis method using petroleum ether as solvent (method 922.06, AOAC International, 2016), and GE using bomb calorimeter analysis (Parr 1241 adiabatic oxygen bomb calorimeter; Parr Instrument Co., Moline, IL). Calculation of NFC was performed according to NRC (2001).

The amount of TMR offered was adjusted daily to yield 5 to $10 \%$ refusal. Daily DMI was calculated as TMR offered minus refused multiplied by the respective DM concentration. Then, DMI was averaged for each cow in each period. Body weight was measured after morning milking and before feeding, starting at approximately $0630 \mathrm{~h}$ on d 14 and 15 , and on d 21 and 22 of each period, and averaged by week for each period. Afternoon $(1630 \mathrm{~h})$ and morning $(0430 \mathrm{~h}) \mathrm{MY}$ were recorded daily. Twelve milk samples were collected for each cow and preserved using bronopol. Samples were from 6 consecutive milkings in wk 3 (d 17 to 20) and 6 consecutive milkings in wk 4 (d 24 to 27). Samples were analyzed for milk fat, true protein, and lactose; SNF and MUN with infrared analyzer using a Foss FT6000 (Foss Electric, Hillerød, Denmark); and SCC using flow cytometry (Agsource Milk Analysis Laboratory, Menomonie, WI). Analytical results were weighted for corresponding yields of morning and afternoon milk to calculate milk composition. The FPCM was calculated as described in IDF (2010) to standardize for $4 \%$ milk fat and $3.3 \%$ milk protein. Feed efficiency was computed by dividing either MY or FPCM by DMI.

\section{Enteric Methane Measurement}

At the beginning of the experiment, 14 Holstein and 14 Jersey cows were trained for $10 \mathrm{~d}$ to adapt to the GreenFeed system (C-Lock Inc., Rapid City, SD), which is a mobile, open-circuit gas measurement unit, considered a non-invasive technique with minimal animal disturbance (Dorich et al., 2015). Details of the equipment, measurement protocol, and calculation of flux have been descried elsewhere (Hristov et al., 2015; 
Huhtanen et al., 2015). In our study, about $300 \mathrm{~g}$ of bait feed mixture (Table 1) were dispensed in 6 aliquots at 45-s intervals to entice cows to place and maintain their forehead near the air inlet of the GreenFeed unit for sufficient time to obtain a reliable measurement. After training, we randomly selected 12 Holstein and 12 Jersey cows to participate in the study. From d 17 to 20 of each period, 8 measurements (lasting $5 \mathrm{~min}$ each) were conducted over $4 \mathrm{~d}$ (2 measurements per day) on each cow. Sampling times were staggered across days to obtain 1 measurement for every $3 \mathrm{~h}$ of a 24 -h clock, as described by Sun et al. (2019). The bait feed mixture was included either in the TMR or through the grain dispenser of the GreenFeed unit during the days of enteric $\mathrm{CH}_{4}$ measurement, such that bait feed was included in DMI calculation. Calibration and $\mathrm{CO}_{2}$ recovery tests were performed at the beginning and end of measurements in each period, as described by Hristov et al. (2015). The measured gas concentrations were adjusted based on the $\mathrm{CO}_{2}$ recovery value, which was $100 \pm 1.3 \%$. Enteric $\mathrm{CH}_{4}$ production was calculated by averaging 8 time point measurements for each cow in each period. Body weight, DMI, and FPCM data of wk 3 were used to calculate $\mathrm{CH}_{4}$ per unit of metabolic BW, $\mathrm{CH}_{4}$ yield, and $\mathrm{CH}_{4}$ intensity, respectively.

\section{Apparent Nutrient Digestibility}

Total collection of feces and urine was performed for $72 \mathrm{~h}$ using 8 cows (1 randomly selected Latin square from each breed), starting at $1800 \mathrm{~h}$ on d 24 and ending at $1800 \mathrm{~h}$ on d 27 of each period. Stalls were individualized with wooden partitions that included an open space or window, allowing cows to socialize with their neighbors. Feces were collected in a stainless steel pan fitted in the gutter beneath the grate. No bedding was added to stalls, to avoid fecal contamination, but manure was scrapped in the pan as needed around the clock to ensure cow cleanliness and measurement precision. Cows were followed to and from the parlor, to collect any feces excreted during milking. Indwelling Foley catheters (24 French, 75-mL balloons; C. R. Bard Inc., Covington, GA) were inserted into the bladder for urine collection in closed containers with $300 \mathrm{~mL}$ of $50 \%$ sulfuric acid solution (weight basis). Excretion of feces and urine were determined gravimetrically every 8 $\mathrm{h}$, leading to 9 samples for each cow in each period. At each sampling time, samples of feces (500 g) and urine $(100 \mathrm{~mL})$ were collected and stored at $-20^{\circ} \mathrm{C}$ until further analysis.

Urine samples were thawed at room temperature and composited by cow (equal volume from each sample) and period. Urine samples were then analyzed in duplicate for total $\mathrm{N}$, using the combustion method as previ- ously described for feed samples. Fecal samples were dried at $60^{\circ} \mathrm{C}$ in a forced-air oven for $96 \mathrm{~h}$, ground to pass a 1-mm screen in a Wiley mill (Arthur H. Thomas Co., Philadelphia, PA), and then composited by cow and period. Aiming to determine accurate nutrient intake during the $3 \mathrm{~d}$ of total collection, refusals from each cow were collected daily and stored at $-20^{\circ} \mathrm{C}$ until further analysis. After drying and grinding individual samples as described, a composite sample was generated for each cow in each period. Composited fecal and refusal samples were then analyzed in duplicate for absolute DM, starch, NDF, ADF, lignin, ash, total N, crude fat, and GE as described earlier for feed samples.

Nutrient intake (DM, OM, NDF, ADF, hemicellulose, and cellulose) was calculated by multiplying DMI by respective nutrient concentrations in the diets. Nutrients excreted via feces were calculated by multiplying fecal DM output by the respective nutrient concentration in feces. Total-tract apparent digestibility was expressed on a percentage basis after the amount of nutrient apparently digested was calculated via the difference between intake and fecal excretion.

\section{Digestive and Metabolic Partitioning of Energy and N}

In this experiment, we measured daily dietary energy input and output in feces, urine, methane, and milk. Thus, we used the following equation to describe energy partitioning:

$$
\mathrm{E}_{\mathrm{B}}=\mathrm{GE}_{\mathrm{I}}-\left(\mathrm{E}_{\mathrm{F}}+\mathrm{E}_{\mathrm{U}}+\mathrm{E}_{\mathrm{CH} 4}+\mathrm{NE}_{\mathrm{M}}+\mathrm{NE}_{\mathrm{L}}\right),
$$

where all terms are in megacalories per day; $\mathrm{E}_{\mathrm{B}}$ is energy balance, which represented an aggregate estimate of energy in pools not measured and compounded errors of measurements; $\mathrm{GE}_{\mathrm{I}}$ is $\mathrm{GE}$ intake; $\mathrm{E}_{\mathrm{F}}$ is fecal energy; $\mathrm{E}_{\mathrm{U}}$ is urinary energy; $\mathrm{E}_{\mathrm{CH} 4}$ is $\mathrm{CH}_{4}$ energy; $\mathrm{NE}_{\mathrm{M}}$ is net energy for maintenance $\left(0.80 \mathrm{Mcal} / \mathrm{kg}\right.$ of $\mathrm{BW}^{0.75}$; NRC 2001); and $\mathrm{NE}_{\mathrm{L}}$ is net energy for lactation per kilogram of milk, calculated using the following NRC (2001) equation: $\mathrm{NE}_{\mathrm{L}}(\mathrm{Mcal} / \mathrm{kg})=0.0929 \times$ fat $\%+$ $0.0547 \times \mathrm{CP} \%+0.192$.

Similarly, we measured daily $\mathrm{N}$ intake and output in feces, urine, and milk. Thus, we used the following equation to describe $\mathrm{N}$ partitioning:

$$
\mathrm{N}_{\mathrm{B}}=\mathrm{N}_{\mathrm{I}}-\left(\mathrm{N}_{\mathrm{F}}+\mathrm{N}_{\mathrm{U}}+\mathrm{N}_{\mathrm{L}}\right),
$$

where all terms are in grams per day; $\mathrm{N}_{\mathrm{B}}$ is $\mathrm{N}$ balance, which represented an aggregate estimate of $\mathrm{N}$ in pools not measured and the compounded error of measurements; $\mathrm{N}_{\mathrm{I}}$ is $\mathrm{N}$ intake; $\mathrm{N}_{\mathrm{F}}$ is fecal $\mathrm{N}$; $\mathrm{N}_{\mathrm{U}}$ is urinary $\mathrm{N}$; and $\mathrm{N}_{\mathrm{L}}$ is milk $\mathrm{N}$. Total $\mathrm{N}$ excretion (or manure $\mathrm{N}$ ) was calculated as $\mathrm{N}_{\mathrm{F}}+\mathrm{N}_{\mathrm{U}}$. 


\section{Measuring Ruminal VFA and Ammonia Nitrogen}

An approximately 10-mL ruminal fluid sample was collected via rumenocentisis (Nordlund and Garrett, 1994) from each cow in each period approximately 4 $\mathrm{h}$ after feeding on d 27 (12 cows) and d 28 (12 cows). The $\mathrm{pH}$ was measured immediately (Laqua Twin $\mathrm{pH}-$ meter model B-713; Spectrum Technologies Inc., Plainfield, IL). Then, a 1-mL aliquot was transferred to a microfuge tube containing $20 \mu \mathrm{L}$ of a $50 \%$ sulfuric acid solution for ruminal VFA analysis. Another 1-mL ruminal fluid sample was transferred to another microfuge tube containing $20 \mu \mathrm{L}$ of $50 \%$ trichloroacetic acid solution for ruminal $\mathrm{NH}_{3}-\mathrm{N}$ analysis. Both samples were stored at $-20^{\circ} \mathrm{C}$ and thawed at room temperature the day of analysis. Ruminal $\mathrm{NH}_{3}-\mathrm{N}$ analysis was performed as per Chaney and Marbach (1962). For VFA, thawed samples were vortexed and centrifuged at 25,000 $\times g$ at $4^{\circ} \mathrm{C}$ for $10 \mathrm{~min}$. The supernatant was transferred to vials for analysis in GC (Phenomenex ZB-FFAP $30 \mathrm{~mL}$ $\times 0.32 \mathrm{~mm}$ ID $\times 0.25 \mu \mathrm{m}$ FT; Shimadzu GC-2010 plus, Shimadzu Corporation, Kyoto, Japan).

\section{Statistical Analysis}

All response variables were reduced to 1 mean value for each cow in each period, and data were analyzed in SAS (version 9.4; SAS Institute Inc., Cary, NC) using Proc Mixed, using the following model:

$$
\begin{gathered}
\mathrm{Y}_{\mathrm{ijklmn}}=\mu+\mathrm{B}_{\mathrm{i}}+\mathrm{Sq}_{\mathrm{j}: \mathrm{i}}+\mathrm{C}_{\mathrm{k}: \mathrm{ji}}+\mathrm{P}_{1}+\mathrm{F}_{\mathrm{m}}+\mathrm{S}_{\mathrm{n}} \\
+\mathrm{FS}_{\mathrm{mn}}+\mathrm{BF}_{\mathrm{im}}+\mathrm{BS}_{\mathrm{in}}+\mathrm{BFS}_{\mathrm{imn}}+\mathrm{E}_{\mathrm{ijklmn}},
\end{gathered}
$$

where $\mathrm{Y}_{\mathrm{ijklmn}}$ is the response variable; $\mu$ is the overall mean; $\mathrm{B}_{\mathrm{i}}$ is the fixed effect of ith breed, $\mathrm{i}=1,2$; $\mathrm{Sq}_{\mathrm{j}: \mathrm{i}}$ is the random effect of $\mathrm{jth}$ square within ith breed, $\mathrm{j}=1$, $2,3, \sim N\left(0, \sigma_{\mathrm{sq}}^{2}\right) ; \mathrm{C}_{\mathrm{k}: \mathrm{ji}}$ is the random effect of kth cow within ith breed and jth square, $\mathrm{k}=1,2, \ldots 24$, $\sim N\left(0, \sigma_{\mathrm{c}}^{2}\right) ; \mathrm{P}_{1}$ is the fixed effect of lth period, $1=1,2$, 3,$4 ; \mathrm{F}_{\mathrm{m}}$ is the fixed effect of $\mathrm{mth}$ FNDF level, $\mathrm{m}=1$, $2 ; \mathrm{S}_{\mathrm{n}}$ is the fixed effect of nth FNDF source, $\mathrm{n}=1,2$; $\mathrm{FS}_{\mathrm{mn}}$ is the interaction term of mth FNDF level with nth FNDF source; $\mathrm{BF}_{\mathrm{im}}$ is the interaction term of ith breed with mth FNDF level; $\mathrm{BS}_{\text {in }}$ is the interaction term of ith breed with nth FNDF source; $\mathrm{BFS}_{\mathrm{imn}}$ is a 3 -way interaction term of ith breed, mth FNDF level, and nth FNDF source; and $E_{\mathrm{ijk} k m n}$ is the subplot error term $\sim N\left(0, \sigma_{\mathrm{e}}^{2}\right)$, with denominator degrees of freedom of 63 , whereas denominator degrees of freedom for the whole-plot error term was 4 .

In the case of variables related to nutrient digestibility and metabolism, the square effect was removed from the model. Least squares means were reported, and significance was declared at $P \leq 0.05$. Interactions were reported and discussed only when significance was declared.

\section{RESULTS AND DISCUSSION}

\section{Chemical Composition of the Diets}

In this study, we intended to explore the effects of level and primary source of FNDF in diets balanced to be isonitrogenous, isoenergetic, and with similar levels of starch, RDP, and RUP. All 4 diets had similar contents of OM, ADF, cellulose, starch, fat, NFC, GE, and $\mathrm{NE}_{\mathrm{L}}$, averaging $92.0,22.4,19.4,22.5,2.3$, and $41.5 \%$ of $\mathrm{DM}$, and 4.38 and $1.52 \mathrm{Mcal} / \mathrm{kg}$ of DM, respectively (Table 1). Dietary CP content was slightly greater (averaged $17.0 \%$, DM basis) than we intended (16.5\%) because AS was harvested at an earlier-than-anticipated vegetative stage. The predicted RDP and RUP were similar across diets and averaged 10.8 and $6.2 \%$ (DM basis), respectively (NRC, 2001). On average, HF diets contained about 13.6 units greater forage ( 54.5 vs. $68 \%$ of DM), 4.8 units greater FNDF (19.2 vs. $24 \%$ of DM), and 5.6 units lower non-forage NDF (12.5 vs. $6.9 \%$ of DM) than the LF diets. As anticipated, the ratio of AS NDF to CS NDF for high AS-based diets (LFAS and HFAS) and high CS-based diets (LFCS and HFCS) were maintained at 70:30 and 30:70, respectively. However, compared with AS, CS-based diets had 3 units greater NDF (30 vs. 33\%) due to greater content of non-forage NDF (8.2 vs. 11.3\%), associated primarily with greater content of soyhulls (Table 1).

\section{Intake, Production Performance, and Feed Efficiency}

Main effects of diet and breed on measurements of intake, lactation performance, and feed efficiency are shown in Table 2. The only interactions detected in this study, which indicated that the difference in DMI between breed depended on forage source (and vice versa), are shown in Figure 1. Although Holsteins had on average $34 \%$ greater DMI $(\mathrm{kg} / \mathrm{d})$ than Jersey cows (Table 2), this difference was wider when the main forage source was AS compared with CS (41 vs. 28\%, respectively; Figure 1A). Similarly, CS-fed cows had on average $7 \%$ greater DMI than AS-fed cows, but this difference was wider for Jerseys (13.5\%) than for Holsteins (3\%; Figure 1A). Lower rumen fill, associated with greater NDF digestibility of the CS- compared with the AS-based diet (57.8 vs. $54.7 \%$, respectively; Table 3) may have contributed to the greater intake of DM for cows fed the former compared with the later diets. In agreement with our results, Hassanat et al. 
(2013) reported that increasing CS at the expense of AS in the diet increased DMI; but these results are in contrast to those reported by Arndt et al. (2015a). Expressed as a percentage of BW, DMI was $10 \%$ lower for Holstein than for Jersey cows (Table 2). Jersey cows may have spent greater rumination time per kilogram of DMI, leading to slower rate of passage and thus greater DMI per unit of BW (Aikman et al., 2008); however, the superiority of Jersey cow was narrower when the main forage source was AS compared with CS (5 vs. 13\%; Figure 1B). Compared with HF, LF-fed cows consumed $9 \%$ greater DM (Table 2). Contrary to our findings, Aguerre et al. (2011) reported no change in DMI when FNDF level gradually increased from 19 to $28 \%$ of dietary DM. This discrepancy may be explained in part by the chemical fraction that decreased as FNDF increased: starch in Aguerre et al. (2011) but non-forage NDF in this study.

Compared with Jerseys, Holstein cows produced $56 \%$ more milk (33 vs. $21 \mathrm{~kg} / \mathrm{d}$ ); however, the magnitude of difference decreased to $33 \%$ when production was expressed as FPCM (33 vs. $25 \mathrm{~kg} / \mathrm{d}$ ). Similar or even greater production differences between Holsteins and Jerseys have been reported elsewhere (Kauffman and St-Pierre, 2001; Knowlton et al., 2010; Olijhoek et al., 2018). Compared with Jerseys, Holstein cows had 16.5\% greater efficiency (MY/DMI), but both breeds had the same efficiency when expressed as FPCM/DMI. Compared with HF, LF-fed cows produced more milk fat, protein, and lactose, due in part to greater MY and in part to greater concentration of milk protein and lactose (Table 2). In addition, LF-fed cows were $5.5 \%$ (MY/DMI) and 4.8\% (FPCM/DMI) less efficient than HF-fed cows. Compared with AS, CS-fed cows had greater MY, FPCM, milk component yield, and milk protein concentration (Table 2) but were less efficient (4.9\% for $\mathrm{MY} / \mathrm{DMI}$ and $4.2 \%$ for $\mathrm{FPCM} / \mathrm{DMI})$. In contrast to our study, others found no effects of forage level or source on feed efficiency (Aguerre et al., 2011; Arndt et al., 2015a).

Table 2. Effects of dietary treatment and breed on intake, milk and milk component yield, milk composition, and feed efficiency $(\mathrm{n}=24$; data from wk 3 and 4 )

\begin{tabular}{|c|c|c|c|c|c|c|c|c|c|c|c|}
\hline Item & \multicolumn{5}{|c|}{ Dietary treatment ${ }^{1}$} & \multicolumn{3}{|c|}{ Breed } & \multicolumn{3}{|c|}{$P$-value ${ }^{2}$} \\
\hline $\mathrm{DM},{ }^{3} \mathrm{~kg} / \mathrm{d}$ & 22.5 & 23.6 & 19.9 & 21.9 & 0.66 & 25.2 & 18.8 & 0.81 & $<0.01$ & $<0.01$ & $<0.01$ \\
\hline NDF, $\mathrm{kg} / \mathrm{d}$ & 6.84 & 7.85 & 5.85 & 7.33 & 0.21 & 7.95 & 5.98 & 0.26 & $<0.01$ & $<0.01$ & $<0.01$ \\
\hline Milk, kg/d & 27.5 & 28.0 & 26.0 & 27.0 & 0.76 & 33.2 & 21.3 & 1.04 & $<0.01$ & $<0.01$ & $<0.01$ \\
\hline $\mathrm{FPCM}^{\mathrm{S}} \mathrm{kg} / \mathrm{d}$ & 29.2 & 29.9 & 27.4 & 29.0 & 0.80 & 32.7 & 24.9 & 1.06 & $<0.01$ & $<0.01$ & $<0.01$ \\
\hline Fat, $\mathrm{kg} / \mathrm{d}$ & 1.26 & 1.28 & 1.18 & 1.25 & 0.04 & 1.37 & 1.12 & 0.05 & $<0.01$ & 0.02 & 0.02 \\
\hline Protein, kg/d & 0.87 & 0.91 & 0.81 & 0.85 & 0.02 & 0.97 & 0.76 & 0.03 & $<0.01$ & $<0.01$ & $<0.01$ \\
\hline Lactose, $\mathrm{kg} / \mathrm{d}$ & 1.33 & 1.36 & 1.25 & 1.30 & 0.04 & 1.61 & 1.01 & 0.05 & $<0.01$ & 0.02 & $<0.01$ \\
\hline \multicolumn{12}{|l|}{ Milk composition } \\
\hline \multicolumn{12}{|l|}{ Feed efficiency ${ }^{7}$} \\
\hline Milk/DMI & 1.24 & 1.18 & 1.31 & 1.25 & 0.04 & 1.34 & 1.15 & 0.04 & $<0.01$ & $<0.01$ & 0.05 \\
\hline FPCM/DMI & 1.33 & 1.26 & 1.38 & 1.34 & 0.04 & 1.31 & 1.35 & 0.04 & $<0.01$ & 0.01 & 0.56 \\
\hline
\end{tabular}

${ }^{1}$ LFAS $=$ low-forage (19.0\%) NDF with a 70:30 ratio of alfalfa silage (AS) NDF to corn silage (CS) NDF; LFCS = low-forage (19.0\%) NDF with a 30:70 ratio of AS NDF to CS NDF; HFAS = high-forage (24.0\%) NDF with a 70:30 ratio of AS NDF to CS NDF; HFCS = high-forage (24.0\%) NDF with a 30:70 ratio of AS NDF to CS NDF.

${ }^{2}$ Significant interactions are shown in footnotes. However, interaction between Forage NDF $($ FNDF) level $\times$ Forage NDF source was not significant $(P>0.05)$

${ }^{3}$ Forage NDF source $\times$ breed interaction $(P=0.04)$ is shown in Figure 1A.

${ }^{4}$ Forage NDF source $\times$ breed interaction $(P<0.01)$ is shown in Figure 1B.

${ }^{5} \mathrm{FPCM}=$ fat- and protein-corrected milk, calculated as per IDF (2010).

${ }^{6} \mathrm{SCC}=\times 10^{3}$ cells $/ \mathrm{mL}$.

${ }^{7}$ Feed efficiency calculated as [Milk yield or FPCM $\left.(\mathrm{kg} / \mathrm{d})\right] /[\mathrm{DMI}(\mathrm{kg} / \mathrm{d})]$. 


\section{Total-Tract Apparent Digestibility of Nutrients}

Compared with Jerseys, Holstein cows consumed greater amounts of $\mathrm{OM}, \mathrm{N}, \mathrm{NDF}, \mathrm{ADF}$, hemicellulose, and cellulose, mainly because of $34 \%$ greater DMI $(P$ $<0.01$; Table 3). However, breed affected none of the apparent digestibility coefficients (Table 3 ). In contrast to our findings, Aikman et al. (2008) reported about 3 percentage unit greater ADF and NDF digestibility for Jerseys than for Holstein cows, whereas several other studies did not find breed differences for DM and NDF digestibility (Kauffman and St-Pierre, 2001; Knowlton et al., 2010). Compared with HF, LF-fed cows also had greater N (8\%), NDF (10\%), ADF (8\%), hemicellulose (21\%), and cellulose (11\%) intake, again mainly due to greater DMI. Except for N, LF-fed cows had greater digestibility of all measured nutrients, most importantly hemicellulose (10\%) and cellulose (4\%), than did

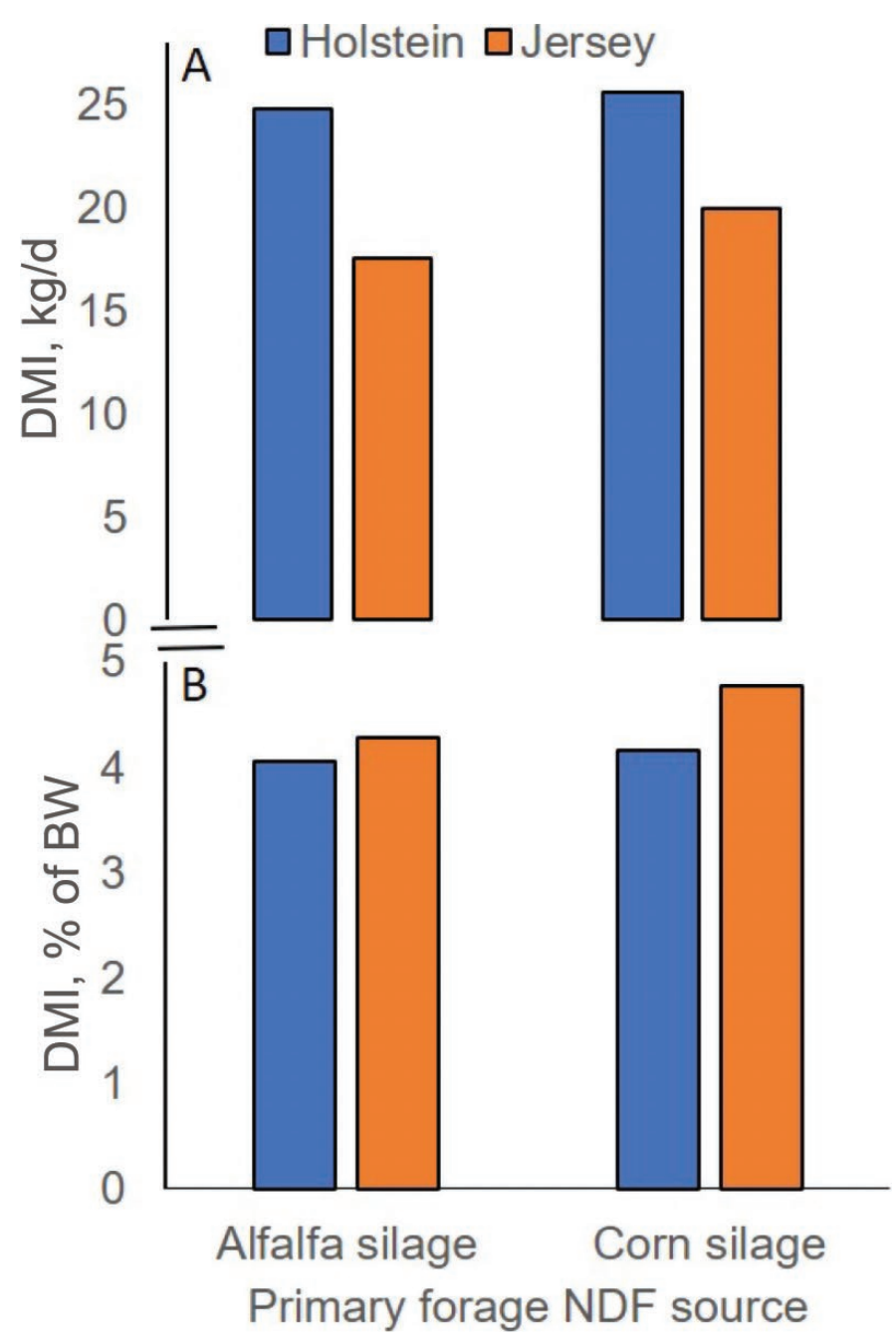

Figure 1. Interaction between breed and forage NDF source on DMI, expressed as $\mathrm{kg} / \mathrm{d}(\mathrm{A} ; P=0.04)$ and $\%$ of $\mathrm{BW}(\mathrm{B} ; P<0.01)$.
HF-fed cows (Table 3). In comparison, Olijhoek et al. (2018) reported a decrease in NDF digestibility when forage level in the diet decreased from 68 to $39 \%$ (DM basis), an effect likely due to a substantial increase in dietary starch content. In our study, however, starch content was kept constant across diets, but level of nonforage NDF varied when dietary forage level was manipulated. Compared with AS, CS-fed cows consumed greater amounts of all nutrients (Table 3) and had greater digestibility of NDF (6\%), hemicellulose (41\%), and cellulose (5\%). In contrast to our findings, Arndt et al. (2015a) and Hassanat et al. (2013) reported greater NDF digestibility coefficients for AS-fed cows than for CS-fed cows.

\section{Enteric Methane $\left(\mathrm{CH}_{4}\right)$ Emissions}

Holstein cows produced $22 \%$ more (471 vs. $385 \mathrm{~g} / \mathrm{d}$ ) $\mathrm{CH}_{4}$ than did Jersey cows, but emission per unit of BW was $17 \%$ lower (0.77 vs. $0.93 \mathrm{~g} / \mathrm{kg}$ of BW) for Holsteins than for Jersey cows. Breed did not affect enteric $\mathrm{CH}_{4}$ yield and intensity, except when expressed as $\mathrm{g} / \mathrm{kg}$ of MY (Table 4). Olijhoek et al. (2018) reported no difference in $\mathrm{CH}_{4}$ intensity between breeds; however, they found greater yield of $\mathrm{CH}_{4}(\mathrm{~g} / \mathrm{kg}$ of DMI) for Jerseys than for Holsteins. Thus, if the goal was to produce a fixed amount of FPCM, then GHG emission at animal level (enteric $\mathrm{CH}_{4}$ ) would be similar for both breeds. Contrary to expectation, LF-fed cows had greater $\mathrm{CH}_{4}$ production than did HF-fed cows (5 to $6 \%$, depending on mode of expression). However, in this study, the replacement of FNDF with non-forage NDF in the diets may have enhanced methanogenesis for multiple reasons. First, we found a strong correlation between DMI and level of soyhulls in the diet [DMI $(\mathrm{kg} / \mathrm{d})=19.3+$ $0.237 \times$ soyhulls $(\%$ of dietary $\left.\mathrm{DM}), \mathrm{R}^{2}=0.99, \mathrm{n}=4\right]$. In addition, the greater ruminal digestibility of soyhull NDF compared with FNDF (Firkins, 1997) should also be conducive to greater methanogenesis. Our results suggested that $\mathrm{CH}_{4}$ production was highly associated with the level of soyhulls in the diet $\left[\mathrm{CH}_{4}(\mathrm{~g} / \mathrm{d})=407\right.$ $+1.842 \times$ soyhulls $(\%$ of dietary $\mathrm{DM}), \mathrm{R}^{2}=0.73, \mathrm{n}$ $=4]$. Increasing $\mathrm{CS} \mathrm{NDF}$ at the expense of AS NDF decreased $\mathrm{CH}_{4}$ yield, expressed as $\mathrm{g} / \mathrm{kg}$ of DMI (8\%), or $\mathrm{g} / \mathrm{kg}$ of NDF intake $(17 \%)$, or $\mathrm{g} / \mathrm{kg}$ of FNDF intake $(8 \%)$. In agreement with our results, total (Hassanat et al., 2013) and partial (Arndt et al., 2015a) replacement of $\mathrm{AS}$ with $\mathrm{CS}$ in the diet decreased $\mathrm{CH}_{4}$ per $\mathrm{kg}$ of DMI. Lower $\mathrm{CH}_{4}$ yield for CS-based diet compared with diets based on grass silage has been reported by Hammond et al. (2016). Taken together, these results disagree with the suggestion of greater emission of $\mathrm{CH}_{4}$ per kilogram of DMI for C4 grass (e.g., corn) than for cold-season legumes such as alfalfa (Archimède et al., 2011). In 
contrast to the work of Hassanat et al. (2013), Arndt et al. (2015a), and Hammond et al. (2016), dietary starch was constant in our study. However, soyhulls, which were used as a source of non-forage NDF to compensate for the decrease in NDF between the HF and LF diets (and to a lesser extent to help maintain the starch level constant between the CS- and AS-based diets) may have contributed to some of the emissions results reported here. Smaller particle size and lower lignification of non-forage NDF of soyhulls compared with FNDF may have enhanced the rate of passage and ruminal digestibility of NDF, respectively, both of which may have alleviated rumen fill and enhanced DMI of cows fed LF diets compared with those fed the HF diets.

\section{Ruminal $\mathrm{pH}, \mathrm{VFA}$, and $\mathrm{NH}_{3}-\mathrm{N}$}

Breed did not affect ruminal $\mathrm{pH}, \mathrm{NH}_{3}-\mathrm{N}$, total VFA concentration, or any molar proportion of VFA except for that of isovalerate, which was greater in Holsteins than in Jerseys (Table 5). Compared with LF, HF-fed cows had greater ruminal $\mathrm{pH}$ (5.93 vs. 6.03). Aguerre et al. (2011) also reported an increase in ruminal $\mathrm{pH}$ from 6.38 to 6.59 when forage level increased from 47 to $68 \%$ of dietary DM. In spite of almost identical CP, compared with LF, HF-fed cows had $1.75 \mathrm{mg} / \mathrm{dL}$ more ruminal $\mathrm{NH}_{3}-\mathrm{N}$ concentration, which is in disagreement with the findings of Aguerre et al. (2011). In our study, altering the FNDF level did not influence total VFA (mean \pm SE: $123 \pm 3.74 \mathrm{mM}$ ), a result similar to that of Aguerre et al. (2011). However, LF-fed cows had lower acetate, greater propionate (molar proportion), and lower acetate-to-propionate ratio (3.78 vs. 4.17), which may have contributed to the observed reduction in $\mathrm{CH}_{4}$ per unit of NDF intake compared with HF-fed cows. Compared with AS, CS-fed cows had lower total VFA (119 vs. $127 \mathrm{mM}$ ) but greater molar proportion of butyrate (11.3 vs. $12 \mathrm{~mol} / 100 \mathrm{~mol})$. In other studies, increasing the proportion of CS in the diet either did not affect butyrate (Arndt et al. 2015a) or decreased butyrate (Hassanat et al., 2013). This inconsistency may be due in part to the strategy used when constructing experimental diets to compare AS with CS. In our study, starch level was kept constant but non-forage NDF varied, whereas in the 2 studies cited above starch level varied and non-forage NDF was kept constant.

\section{Feces and Urine}

The amount excreted and the characterization of manure are important variables in the context of nutrient management and the modeling of whole-farm economic and environmental performance (Pellerin et al., 2017; Uddin 2019). Holstein cows produced greater amounts of feces as-is (36\%), urine as-is (14\%), manure as-is (29\%), feces DM (37\%), and urine DM (20\%) than did Jersey cows. These results are associated with differences in BW and DMI between the 2 breeds, and they were of almost identical magnitude, as reported by Knowlton et al. (2010). Level of FNDF did not af-

Table 3. Effects of dietary treatment and breed on nutrient intake and total-tract apparent digestibility $(\mathrm{n}=8$; wk 4 data)

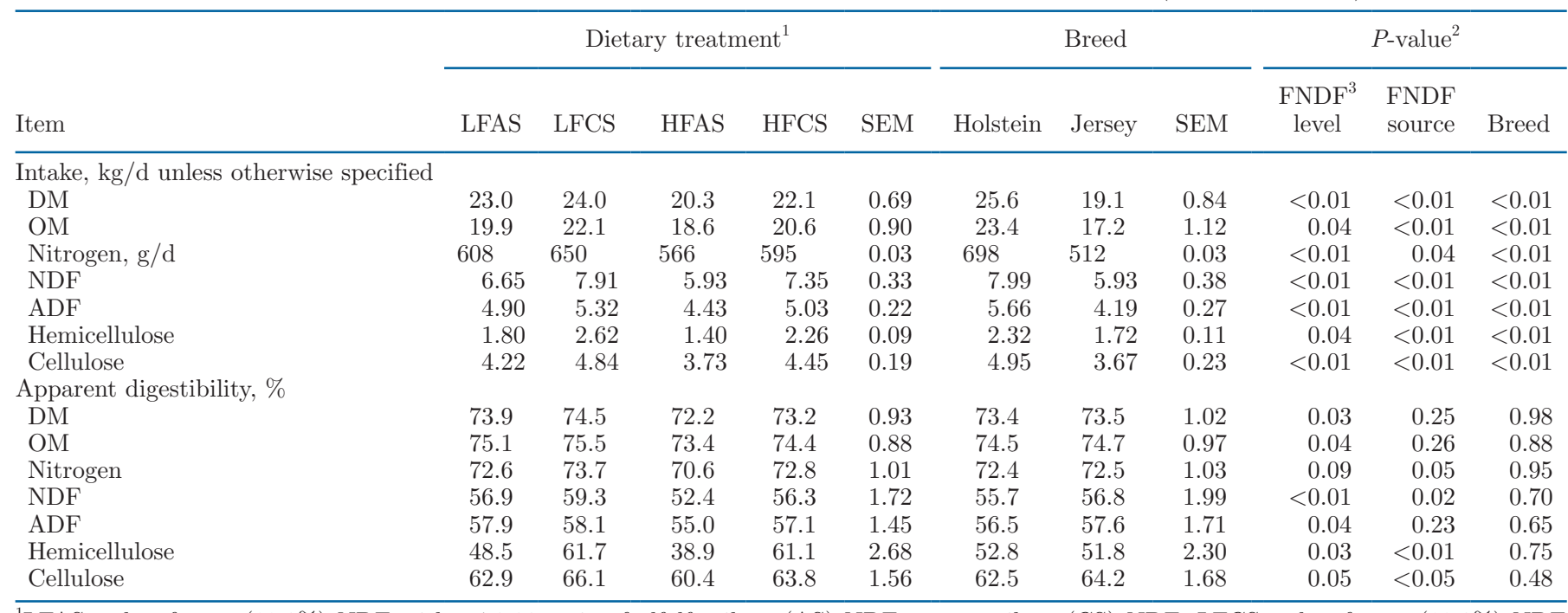

${ }^{1}$ LFAS $=$ low-forage (19.0\%) NDF with a 70:30 ratio of alfalfa silage (AS) NDF to corn silage (CS) NDF; LFCS = low-forage (19.0\%) NDF with a 30:70 ratio of AS NDF to CS NDF; HFAS = high-forage (24.0\%) NDF with a 70:30 ratio of AS NDF to CS NDF; HFCS = high-forage $(24.0 \%)$ NDF with a 30:70 ratio of AS NDF to CS NDF.

${ }^{2} P$-values for all main effects (significant plus non-significant) are presented, but non-significant interaction effects are not shown in this table. ${ }^{3} \mathrm{FNDF}=$ forage NDF. 
Table 4. Effects of dietary treatment and breed on enteric methane $\left(\mathrm{CH}_{4}\right)$ emission $(\mathrm{n}=24$; wk 3 data)

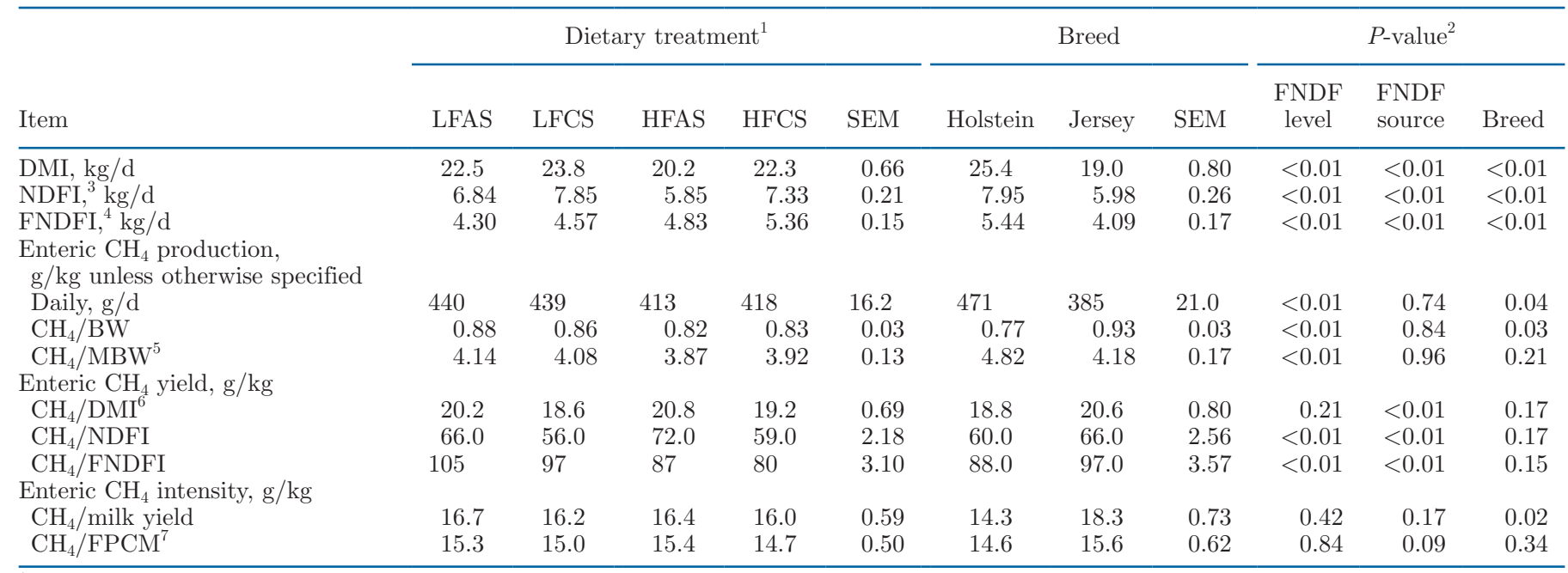

${ }^{1}$ LFAS $=$ low-forage (19.0\%) NDF with a 70:30 ratio of alfalfa silage (AS) NDF to corn silage (CS) NDF; LFCS $=$ low-forage (19.0\%) NDF with a 30:70 ratio of AS NDF to CS NDF; HFAS = high-forage (24.0\%) NDF with a 70:30 ratio of AS NDF to CS NDF; HFCS = high-forage (24.0\%) NDF with a $30: 70$ ratio of AS NDF to CS NDF.

${ }^{2}$ None of the interaction effects were significant (data not shown). FNDF $=$ forage NDF.

${ }^{3} \mathrm{NDFI}=\mathrm{NDF}$ intake.

${ }^{4} \mathrm{FNDFI}=$ forage NDF intake.

${ }^{5} \mathrm{MBW}=$ metabolic body weight, calculated as $\mathrm{BW}^{0.75}$.

${ }^{6}$ Based on DMI measured on wk 3 (same week as enteric $\mathrm{CH}_{4}$ measurement).

${ }^{7} \mathrm{FPCM}=$ fat- and protein-corrected milk, calculated as per IDF (2010).

fect any of the variables reported in Table 6, which agreed with the findings of Aguerre et al. (2011). However, compared with AS, CS-fed cows produced more feces as-is (14\%) and less urine as-is (16\%). Arndt et al. (2015a) also reported a decrease in urine volume when dietary AS was replaced with CS. This effect might be due to increased $\mathrm{K}$ content with inclusion of a greater proportion of $\mathrm{AS}$ at the expense of CS in the diet. Although we found a lower feces-to-urine ratio for AS-fed cows compared with CS-fed cows (1.65 vs. 2.21; Table 6), the ratio of fecal $\mathrm{N}$ to urinary $\mathrm{N}$ was not altered by forage source (Table 7). Thus, AS-fed cows

Table 5. Effects of dietary treatment and breed on characteristics of ruminal fluid ( $\mathrm{n}=24$; wk 4 data)

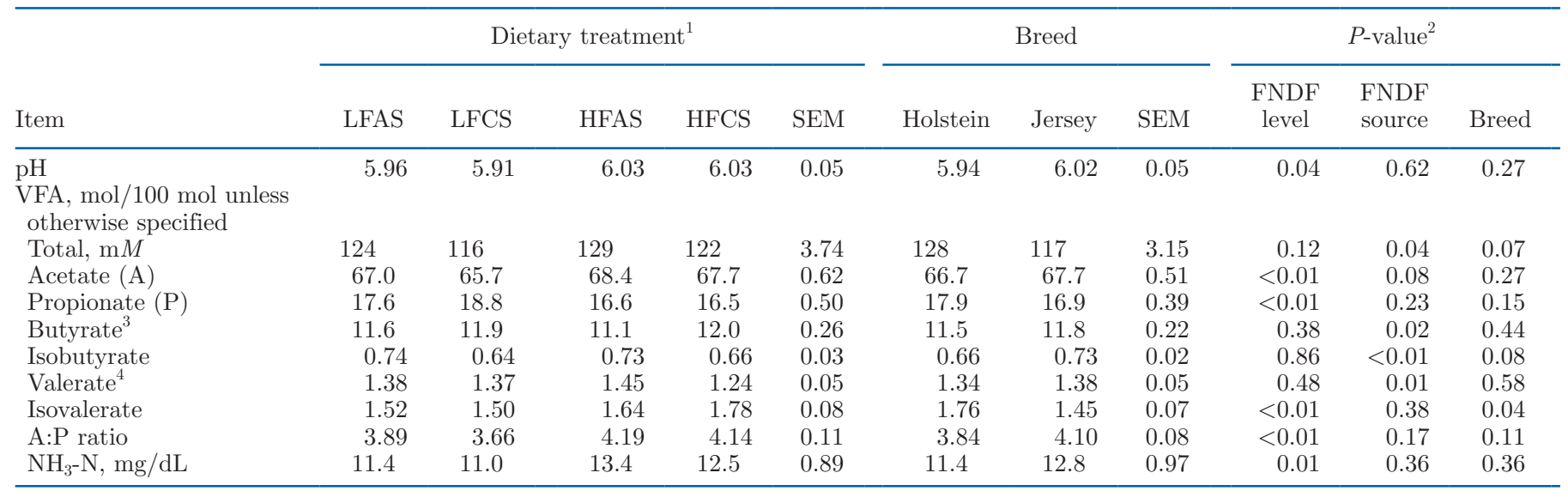

${ }^{1}$ LFAS $=$ low-forage $(19.0 \%)$ NDF with a 70:30 ratio of alfalfa silage (AS) NDF to corn silage (CS) NDF; LFCS = low-forage (19.0\%) NDF with a 30:70 ratio of AS NDF to CS NDF; HFAS = high-forage (24.0\%) NDF with a 70:30 ratio of AS NDF to CS NDF; HFCS = high-forage (24.0\%) NDF with a 30:70 ratio of AS NDF to CS NDF.

${ }^{2}$ Significant interactions are shown in footnotes. FNDF $=$ forage NDF.

${ }^{3}$ Significant FNDF level $\times$ breed $(P=0.02)$.

${ }^{4}$ Significant FNDF level $\times$ FNDF source $(P=0.03)$. 
Table 6. Effects of dietary treatment and breed on manure production and characteristics ( $\mathrm{n}=8$; wk 4 data)

\begin{tabular}{|c|c|c|c|c|c|c|c|c|c|c|c|}
\hline \multirow[b]{2}{*}{ Item } & \multicolumn{5}{|c|}{ Dietary treatment $^{1}$} & \multicolumn{3}{|c|}{ Breed } & \multicolumn{3}{|c|}{$P$-value ${ }^{2}$} \\
\hline & LFAS & LFCS & HFAS & HFCS & SEM & Holstein & Jersey & SEM & $\begin{array}{c}\text { FNDF } \\
\text { level }\end{array}$ & $\begin{array}{l}\text { FNDF } \\
\text { source }\end{array}$ & Breed \\
\hline \multicolumn{12}{|l|}{ Production, kg/d } \\
\hline Feces as is & 38.1 & 43.9 & 39.8 & 45.1 & 1.65 & 48.0 & 35.4 & 1.82 & 0.25 & $<0.01$ & $<0.01$ \\
\hline Urine as is & 24.1 & 19.3 & 23.9 & 21.2 & 0.93 & 23.6 & 20.7 & 0.77 & 0.35 & $<0.01$ & 0.03 \\
\hline Manure $^{3}$ as is & 62.0 & 63.0 & 64.0 & 66.0 & 1.90 & 72.0 & 56.0 & 2.00 & 0.15 & 0.25 & $<0.01$ \\
\hline \multicolumn{12}{|l|}{ Ratios, ${ }^{4} \mathrm{~kg} / \mathrm{kg}$} \\
\hline Feces/urine & 1.62 & 2.26 & 1.67 & 2.15 & 0.09 & 2.08 & 1.77 & 0.09 & 0.72 & $<0.01$ & 0.07 \\
\hline Manure/FPCM ${ }^{5}$ & 2.30 & 2.20 & 2.40 & 2.31 & 0.08 & 2.26 & 2.34 & 0.08 & 0.12 & 0.16 & 0.52 \\
\hline
\end{tabular}

${ }^{1}$ LFAS $=$ low-forage $(19.0 \%)$ NDF with a 70:30 ratio of alfalfa silage (AS) NDF to corn silage (CS) NDF; LFCS $=$ low-forage (19.0\%) NDF with a 30:70 ratio of AS NDF to CS NDF; HFAS = high-forage (24.0\%) NDF with a 70:30 ratio of AS NDF to CS NDF; HFCS = high-forage $(24.0 \%)$ NDF with a 30:70 ratio of AS NDF to CS NDF.

${ }^{2}$ None of the interaction effects were significant (data not shown). FNDF $=$ forage NDF.

${ }^{3}$ Sum of feces plus urine only but no bedding materials.

${ }^{4}$ Feces, urine, and manure expressed on as-is basis.

${ }^{5}$ Fat- and protein-corrected milk (FPCM) used in this ratio was calculated as per IDF (2010) formula.

may produce a more liquid manure than CS-fed cows, but volatilization of manure $\mathrm{NH}_{3}$, and the associated indirect nitrous oxide emissions, may not be influenced by forage source.

\section{Digestive and Metabolic Partitioning of Nitrogen}

Intake of $\mathrm{N}$ and excretion via feces, urine, and manure and secretion via milk (expressed as $\mathrm{g} / \mathrm{d}$ ) were greater (from 34 to $38 \%$, depending on the variable) for Holstein than for Jersey cows (Table 7). These results were consistent with greater DMI, feces output, urine output, and manure production reported herein for Holstein compared with Jersey cows. However, in agreement with Aikman et al. (2008) and Knowlton et al. (2010), breed did not affect $\mathrm{N}$ excretion in feces or urine nor milk $\mathrm{N}$ secretion when expressed as a percentage of $\mathrm{N}$ intake in this study. The absence of difference in these rates of conversion suggested that both breeds had similar digestive and metabolic efficiencies for $\mathrm{N}$.

Table 7. Effects of dietary treatment and breed on $\mathrm{N}$ intake and partitioning $(\mathrm{n}=8$; wk 4 data)

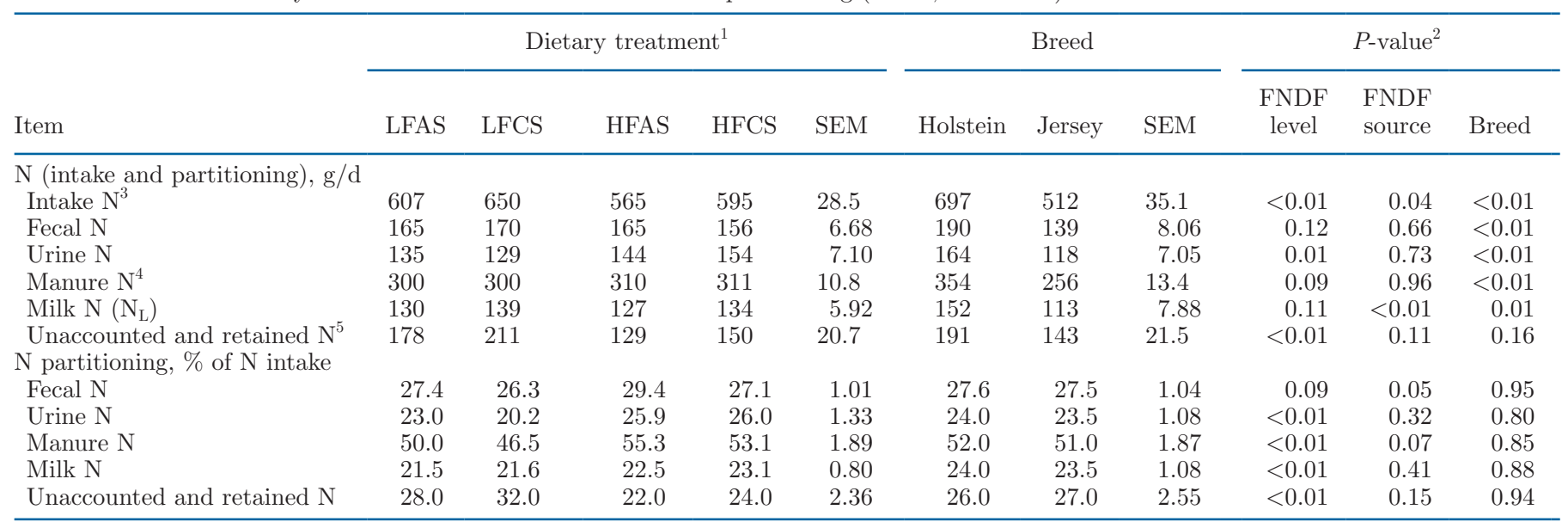

${ }^{1}$ LFAS $=$ low-forage (19.0\%) NDF with a 70:30 ratio of alfalfa silage (AS) NDF to corn silage (CS) NDF; LFCS $=$ low-forage (19.0\%) NDF with a 30:70 ratio of AS NDF to CS NDF; HFAS = high-forage (24.0\%) NDF with a 70:30 ratio of AS NDF to CS NDF; HFCS = high-forage (24.0\%) NDF with a 30:70 ratio of AS NDF to CS NDF.

${ }^{2}$ None of the interaction effects were significant (data not shown). FNDF $=$ forage NDF.

${ }^{3}$ Intake of $\mathrm{N}$ reported in this table (calculated using data from 8 cows collected during total collection of wk 4 data) was numerically different than but statistically the same as $\mathrm{N}$ intake shown in Table 2 (calculated using data from all 24 cows based on both wk 3 and wk 4 data).

${ }^{4}$ Calculated as the sum of fecal plus urinary $\mathrm{N}$ without including bedding $\mathrm{N}$.

${ }^{5}$ Intake $\mathrm{N}-($ Fecal N + Urinary N + Milk N). 
Compared with HF, LF-fed cows had $8 \%$ greater $\mathrm{N}$ intake, lower urinary $\mathrm{N}$ excretion $(-17 \mathrm{~g} / \mathrm{d})$, and lower milk $\mathrm{N}$ use efficiency (22.8 vs. $21.5 \%$; Table 7 ). Compared with AS, CS-fed cows had $6 \%$ greater $\mathrm{N}$ intake, secreted greater milk $\mathrm{N}(+8.0 \mathrm{~g} / \mathrm{d})$, and exhibited lower fecal $\mathrm{N}$ as a percentage of $\mathrm{N}$ intake (26.7 vs. $28.4 \%$ ). Hassanat et al. (2013) also reported an increase in milk $\mathrm{N}$ secretion with increasing CS in the diet. In our study, $\mathrm{N}$ balance ( $\mathrm{N}$ in pools not measured and compounded error of measurements) was influenced by FNDF level, for reasons that remain unclear. One possible contributing factor, however, could have been increased retention of (microbial) $\mathrm{N}$ in the digestive tract associated with greater DMI (Table 2) and apparent total-tract digestibility of NDF (Table 3) when cows were fed the LF compared with the HF diets. Overall, $\mathrm{N}$ balance was surprisingly large, averaging $167 \mathrm{~g} / \mathrm{d}$ (Table 7), and thus should be interpreted with caution. In comparison, Spanghero and Kowalski (1997) compiled $35 \mathrm{~N}$ balance studies and found $\mathrm{N}$ balance ranging from -57 to 205 g/d, whereas Spek et al. (2013) reported a mean ( \pm $\mathrm{SD})$ of $54 \pm 38.8 \mathrm{~g} / \mathrm{d}$ from 55 studies conducted in North America. Because all animals used in this study were primiparous cows in mid- to late lactation, they were gaining weight (mean \pm SD; Holstein ADG: $300 \pm$ $92 \mathrm{~g} / \mathrm{d}$, and Jersey ADG: $240 \pm 192 \mathrm{~g} / \mathrm{d}$ ) and thus were probably using some $\mathrm{N}$ intake for replenishing body tissue lost in early lactation and for further growth toward mature BW (NRC, 2001). These effects, however, were unlikely to entirely explain the high $\mathrm{N}$ balance. Several studies also found positive $\mathrm{N}$ balance with seemingly no change in BW (Kauffman and St-Pierre, 2001; Flis and Wattiaux, 2005). Authors who have reviewed sources of errors in N balance (Spanghero and Kowalski, 1997; Reynolds and Kristensen, 2008) have remained perplexed by an overall positive bias. Recently, however, Edouard et al. (2018) reported that urea nitrogen in the sweat of lactating cows could account for 8 to $21 \%$ of the unaccounted $\mathrm{N}$ (calculated as $\mathrm{N}$ intake - milk $\mathrm{N}$ - fecal $\mathrm{N}-$ urinary $\mathrm{N}$ ). This $\mathrm{N}$ pool was unlikely to have played a substantial role under our experimental conditions because of the mild spring ambient temperature during the study. Nevertheless, the large $\mathrm{N}$ balance values associated with relatively low fecal $\mathrm{N}$ and urinary $\mathrm{N}$ reported here should warrant caution in interpreting our results.

\section{Digestive and Metabolic Partitioning of Energy}

Except for energy balance, all energy-related variables expressed as Mcal/d were affected by breed and were greater (22 to $43 \%$, depending on the variable) in Holstein than in Jersey cows (Table 8). The most likely reasons for greater daily energy values in Holstein were related to their greater body size (48\%) and DMI (34\%) than those of Jerseys. However, breed did not affect any of the energy-related variables expressed as a percentage of $\mathrm{GE}_{\mathrm{I}}$ (Table 8), with percentages comparable to those of other studies conducted separately with Holstein (Arndt et al., 2015b) and Jersey cattle (Judy et al., 2018). The absence of difference in these rates of conversion suggested that both breeds had similar digestive and metabolic efficiencies for energy. Compared with HF, LF-fed cows had $6 \%$ greater $\mathrm{GE}_{\mathrm{I}}$ (98.6 vs. $93.1 \mathrm{Mcal} / \mathrm{d})$, primarily due to greater DMI. The greater $\mathrm{GE}_{\mathrm{I}}$ resulted in increases of 8 and $9 \%$ of $\mathrm{DE}$ and ME (Mcal/d), respectively, for LF-fed cows than for HF-fed cows. Energy balance expressed as Mcal/d was $13 \%$ greater for LF-fed cows than for HFfed cows. When expressed as $\mathrm{Mcal} / \mathrm{d}$, all the variables except urinary energy and $\mathrm{CH}_{4}$ energy were affected by FNDF source being greater in CS-fed cows than in AS-fed cows, due mainly to greater DMI. However, CS-fed cows excreted 15 and 10\% lower urinary energy and $\mathrm{CH}_{4}$ energy, respectively, than AS-fed cows. These reduced energy losses contributed to greater $\mathrm{ME}$ in CS-fed cows than in AS-fed cows. Greater efficiency has been associated with lower energy losses as urinary, $\mathrm{CH}_{4}$, and heat energy (Arndt et al., 2015b). In this study, AS-fed cows (having greater FPCM/DMI) excreted greater energy via urine and $\mathrm{CH}_{4}$ than $\mathrm{CS}$-fed cows (with lower FPCM/DMI). Although no statistical difference occurred in energy balance expressed as percentage of $\mathrm{GE}_{\mathrm{I}}$ (40.5 vs. $43.2 \%$ of $\mathrm{GE}_{\mathrm{I}}$ for $\mathrm{AS}$-fed and CS-fed cows, respectively), the magnitude of the numerical difference may have contributed to the lower efficiency of CS-fed cows compared with AS-fed cows when expressed as FPCM/DMI (Table 2).

\section{CONCLUSIONS}

In conclusion, Holstein cows had greater DMI, FPCM, and $\mathrm{CH}_{4}$ production than did Jersey cows, but breed did not affect digestive and metabolic efficiencies, FPCM/DMI, $\mathrm{CH}_{4}$ yield, or intensity. In contrast to our hypothesis, we found no interactions except for a difficult-to-explain FNDF source $\times$ breed interaction for DMI. Compared with HF, LF-fed cows had lower FPCM/DMI and urinary $\mathrm{N}$ loss (g/d and percentage of $\mathrm{N}$ intake) with similar $\mathrm{CH}_{4}$ intensity and yield, but had greater $\mathrm{CH}_{4}$ production (most likely as a consequence of greater content of soyhulls as a source of non-forage NDF in the LF than in the HF diet). Compared with AS, CS-fed cows had greater DMI and FPCM but lower FPCM/DMI, urinary, and $\mathrm{CH}_{4}$ energy loss, and $\mathrm{CH}_{4}$ yield, without affecting $\mathrm{CH}_{4}$ production and intensity. 
Table 8. Effects of dietary treatments and breed on energy $(\mathrm{E})$ intake and partitioning ( $\mathrm{n}=8$; wk 4 data)

\begin{tabular}{|c|c|c|c|c|c|c|c|c|c|c|c|}
\hline \multirow[b]{2}{*}{ Item } & \multicolumn{5}{|c|}{ Dietary treatment ${ }^{1}$} & \multicolumn{3}{|c|}{ Breed } & \multicolumn{3}{|c|}{$P$-value ${ }^{2}$} \\
\hline & LFAS & LFCS & HFAS & HFCS & SEM & Holstein & Jersey & SEM & $\begin{array}{l}\text { FNDF } \\
\text { level }\end{array}$ & $\begin{array}{l}\text { FNDF } \\
\text { source }\end{array}$ & Breed \\
\hline \multicolumn{12}{|l|}{$\begin{array}{l}\text { Energy expressed } \\
\text { as Mcal/d }\end{array}$} \\
\hline Fecal E & 25.0 & 27.2 & 25.4 & 25.8 & 0.93 & 30.0 & 22.0 & $\begin{array}{l}J .04 \\
1.16\end{array}$ & $\begin{array}{l}0.02 \\
0.31\end{array}$ & $\begin{array}{r}<0.01 \\
0.02\end{array}$ & $\begin{array}{l}<0.01 \\
<0.01\end{array}$ \\
\hline $\mathrm{CH}_{4} \mathrm{E}$ & 5.41 & 5.45 & 5.35 & 5.11 & 0.26 & 6.29 & 4.40 & 0.29 & 0.31 & 0.61 & $<0.01$ \\
\hline $\mathrm{ME}^{5}$ & 61.0 & 68.0 & 55.2 & 63.4 & 3.80 & 71.2 & 52.3 & 4.60 & 0.03 & $<0.01$ & 0.03 \\
\hline Milk $\mathrm{NE}_{\mathrm{L}}{ }^{6}$ & 20.6 & 21.6 & 20.3 & 21.6 & 0.86 & 24.0 & 18.0 & 4.16 & 0.07 & 0.03 & $<0.01$ \\
\hline Maintenance $\mathrm{E}^{7}$ & 8.48 & 8.58 & 8.49 & 8.52 & 0.17 & 10.0 & 7.05 & 0.24 & 0.43 & 0.05 & $<0.01$ \\
\hline E balance $^{8}$ & 40.4 & 46.4 & 34.9 & 41.8 & 3.5 & 47.2 & 34.3 & 4.17 & 0.04 & 0.01 & 0.09 \\
\hline \multicolumn{12}{|l|}{$\begin{array}{l}\text { Energy expressed } \\
\text { as \% of intake }\end{array}$} \\
\hline Milk $\mathrm{NE}_{\mathrm{L}}$ & 22.3 & 21.2 & 22.9 & 22.6 & 1.03 & 22.0 & 22.5 & 1.18 & 0.16 & 0.35 & 0.76 \\
\hline Maintenance E & 9.13 & 8.38 & 9.60 & 8.95 & 0.32 & 9.10 & 8.88 & 0.36 & 0.04 & $<0.01$ & 0.62 \\
\hline E balance & 41.9 & 44.5 & 39.1 & 41.9 & 2.6 & 42.2 & 41.5 & 2.7 & 0.06 & 0.06 & 0.83 \\
\hline
\end{tabular}

${ }^{1}$ LFAS = low-forage (19.0\%) NDF with a 70:30 ratio of alfalfa silage (AS) NDF to corn silage (CS) NDF; LFCS = low-forage (19.0\%) NDF with a 30:70 ratio of AS NDF to CS NDF; HFAS = high-forage (24.0\%) NDF with a 70:30 ratio of AS NDF to CS NDF; HFCS = high-forage $(24.0 \%) \mathrm{NDF}$ with a $30: 70$ ratio of AS NDF to CS NDF.

${ }^{2}$ None of the interaction effects were significant (data not shown). FNDF $=$ forage NDF.

${ }^{3} \mathrm{GE}_{\mathrm{I}}=$ gross energy intake.

${ }^{4} \mathrm{DE}=$ digestible energy: $\mathrm{GE}_{\mathrm{I}}-$ Fecal $\mathrm{E}$.

${ }^{5} \mathrm{ME}=\mathrm{DE}-\left(\right.$ Urinary $\left.\mathrm{E}+\mathrm{CH}_{4} \mathrm{E}\right)$.

${ }^{6}$ Milk NE $\mathrm{L}$ based on Equation 2-15 of NRC (2001).

${ }^{7} 0.080 \mathrm{Mcal} / \mathrm{kg}$ of $\mathrm{BW}^{0.75}$ (NRC, 2001).

${ }^{8} \mathrm{GE}_{\mathrm{I}}-\left(\right.$ Fecal E + Urinary E $+\mathrm{CH}_{4} \mathrm{E}+$ Maintenance E + Milk $\left.\mathrm{NE}_{\mathrm{L}}\right)$.

\section{ACKNOWLEDGMENTS}

This project was financially supported by the National Institute of Food and Agriculture, US Department of Agriculture Hatch Multi-state research formula fund (\# WIS01941, and USDA-NIFA \# 2013-6800220525; Washington, DC). We are thankful to fellow University of Wisconsin (Madison) laboratory members Dominique D'Huvetter, Taylor Wickert, Fei Sun, Paulina Letelier, Sanjeewa Ranathunga, Fernanda De Kassia Gomes, and Benito Albarran Portillo for their suggestions and hard work during sampling. The authors are happy to express their acknowledgement to University of Wisconsin (Madison) laboratory manager Sandy Bertics and veterinarian Michael Maroney for their great help, particularly during rumenocentesis and catheterization, respectively. Finally, the authors also express their gratitude to statistical consultant Peter Crump (College of Agricultural and Life Sciences, UW-Madison) for his help with statistical analysis. The authors have not stated any conflicts of interest.

\section{REFERENCES}

Aguerre, M. J., M. A. Wattiaux, J. M. Powell, G. A. Broderick, and C. Arndt. 2011. Effect of forage-to-concentrate ratio in dairy cow diets on emission of methane, carbon dioxide, and ammonia, lactation performance, and manure excretion. J. Dairy Sci. 94:30813093. https://doi.org/10.3168/jds.2010-4011.

Aikman, P. C., C. K. Reynolds, and D. E. Beever. 2008. Diet digestibility, rate of passage, and eating and rumination behavior of Jersey and Holstein cows. J. Dairy Sci. 91:1103-1114. https://doi .org/10.3168/jds.2007-0724.

Allen, A. G., S. C. Jarvis, and D. M. Headon. 1996. Nitrous oxide emissions from soils due to inputs of nitrogen from excreta return by livestock on grazed grassland in the U.K. Soil Biol. Biochem. 28:597-607. https://doi.org/10.1016/0038-0717(95)00186-7.

AOAC International. 2016. Official Methods of Analysis. 20th ed. AOAC International, Arlington, VA.

Archimède, H., M. Eugène, C. Marie Magdeleine, M. Boval, C. Martin, D. P. Morgavi, P. Lecomte, and M. Doreau. 2011. Comparison of methane production between $\mathrm{C} 3$ and $\mathrm{C} 4$ grasses and legumes. Anim. Feed Sci. Technol. 166-167:59-64. https://doi.org/10.1016/ j.anifeedsci.2011.04.003.

Arndt, C., J. M. Powell, M. J. Aguerre, and M. A. Wattiaux. 2015a. Performance, digestion, nitrogen balance, and emission of manure ammonia, enteric methane, and carbon dioxide in lactating cows fed diets with varying alfalfa silage-to-corn silage ratios. J. Dairy Sci. 98:418-430. https://doi.org/10.3168/jds.2014-8298. 
Arndt, C., J. M. M. Powell, M. J. J. Aguerre, P. M. M. Crump, and M. A. A. Wattiaux. 2015b. Feed conversion efficiency in dairy cows: Repeatability, variation in digestion and metabolism of energy and nitrogen, and ruminal methanogens. J. Dairy Sci. 98:3938-3950. https://doi.org/10.3168/jds.2014-8449.

Chaney, A. L., and E. P. Marbach. 1962. Modified reagents for determination of urea and ammonia. Clin. Chem. 8:130-132. https:// doi.org/10.1093/clinchem/8.2.130.

Dorich, C. D., R. K. Varner, A. B. D. Pereira, R. Martineau, K. J. Soder, and A. F. Brito. 2015. Short communication: Use of a portable, automated, open-circuit gas quantification system and the sulfur hexafluoride tracer technique for measuring enteric methane emissions in Holstein cows fed ad libitum or restricted. J. Dairy Sci. 98:2676-2681. https://doi.org/10.3168/jds.2014-8348.

Edouard, N., A. Suzanne, P. Lamberton, B. Rouille, and P. Faverdin. 2018. Complete nitrogen balance in dairy cows: Does every drop of sweat count? Page 641 in Proc. 10th International Symposium on the Nutrition of Herbivores; Herbivore Nutrition Supporting Sustainable Intensification and Agro-ecological Approaches; Clermont-Ferrand, France. 2018 Animal Consortium (ISSN 20404700); https://symposium.inra.fr/isnh2018.

Firkins, J. L. 1997. Effects of feeding nonforage fiber sources on site of fiber digestion. J. Dairy Sci. 80:1426-1437. https://doi.org/10 $.3168 / j d s . S 0022-0302(97) 76072-7$.

Flis, S. A., and M. A. Wattiaux. 2005. Effects of parity and supply of rumen-degraded and undegraded protein on production and nitrogen balance in Holsteins. J. Dairy Sci. 88:2096-2106. https://doi .org/10.3168/jds.S0022-0302(05)72886-1.

Hall, M. B. 2009. Determination of starch, including maltooligosaccharides, in animal feeds: Comparison of methods and a method recommended for AOAC collaborative study. J. AOAC Int. 92:42-49. https://doi.org/10.1093/jaoac/92.1.42.

Hammond, K. J., A. K. Jones, D. J. Humphries, L. A. Crompton, and C. K. Reynolds. 2016. Effects of diet forage source and neutral detergent fiber content on milk production of dairy cattle and methane emissions determined using GreenFeed and respiration chamber techniques. J. Dairy Sci. 99:7904-7917. https://doi.org/ $10.3168 /$ jds.2015-10759.

Hassanat, F., R. Gervais, C. Julien, D. I. Massé, A. Lettat, P. Y. Chouinard, H. V. Petit, and C. Benchaar. 2013. Replacing alfalfa silage with corn silage in dairy cow diets: Effects on enteric methane production, ruminal fermentation, digestion, $\mathrm{N}$ balance, and milk production. J. Dairy Sci. 96:4553-4567. https://doi.org/10 .3168/jds.2012-6480.

Hristov, A. N., J. Oh, F. Giallongo, T. Frederick, H. Weeks, P. R. Zimmerman, M. T. Harper, R. A. Hristova, R. S. Zimmerman, and A. F. Branco. 2015. The use of an automated system (GreenFeed) to monitor enteric methane and carbon dioxide emissions from ruminant animals. J. Vis. Exp. 103:1-8. https://doi.org/10.3791/ 52904.

Huhtanen, P., E. H. H. Cabezas-Garcia, S. Utsumi, and S. Zimmerman. 2015. Comparison of methods to determine methane emissions from dairy cows in farm conditions. J. Dairy Sci. 98:33943409. https://doi.org/10.3168/jds.2014-9118.

IDF (International Dairy Federation). 2010. A common carbon footprint for dairy: The IDF guide to standard lifecycle assessment methodology for the dairy industry. Bull. International Dairy Federation 445. IDF, Brussels, Belgium. http://www.ukidf.org/ documents/bulletin445.pdf.

Judy, J. V., G. C. Bachman, T. M. Brown-Brandl, S. C. Fernando, K. E. Hales, P. S. Miller, R. R. Stowell, and P. J. Kononoff. 2018. Energy balance and diurnal variation in methane production as affected by feeding frequency in Jersey cows in late lactation. J. Dairy Sci. 101:10899-10910. https://doi.org/10.3168/jds.2018 $-14596$.

Kauffman, A. J. J., and N. R. R. St-Pierre. 2001. The relationship of milk urea nitrogen to urine nitrogen excretion in Holstein and Jersey cows. J. Dairy Sci. 84:2284-2294. https://doi.org/10.3168/ jds.S0022-0302(01)74675-9.
Knowlton, K. F. F., V. A. A. Wilkerson, D. P. P. Casper, and D. R. R. Mertens. 2010. Manure nutrient excretion by Jersey and Holstein cows. J. Dairy Sci. 93:407-412. https://doi.org/10.3168/jds.2009 $-2617$.

Külling, D. R., H. Menzi, T. F. Kröber, A. Neftel, F. Sutter, P. Lischer, and M. Kreuzer. 2001. Emissions of ammonia, nitrous oxide and methane from different types of dairy manure during storage as affected by dietary protein content. J. Agric. Sci., Cambridge 137: 235-250. https://doi.org/10.1017/S0021859601001186.

Martin, N. P., M. P. Russelle, J. M. Powell, C. J. Sniffen, S. I. Smith, J. M. Tricarico, and R. J. Grant. 2017. Invited review: Sustainable forage and grain crop production for the US dairy industry. J. Dairy Sci. 100:9479-9494. https://doi.org/10.3168/jds.2017-13080.

Nordlund, K. V., and E. F. Garrett. 1994. Rumenocentesis: A technique for the diagnosis of subacute rumen acidosis in dairy herds. Bov. Pract. 28:104.

NRC (National Research Council). 2001. Nutrient Requirements of Dairy Cattle. Vol. 7. Rev. ed. Natl. Acad. Sci., Washington, DC.

Olijhoek, D. W., P. Løvendahl, J. Lassen, A. L. F. Hellwing, J. K. Höglund, M. R. Weisbjerg, S. J. Noel, F. McLean, O. Højberg, and P. Lund. 2018. Methane production, rumen fermentation, and diet digestibility of Holstein and Jersey dairy cows being divergent in residual feed intake and fed at 2 forage-to-concentrate ratios. J. Dairy Sci. 101:9926-9940. https://doi.org/10.3168/jds.2017-14278.

Pellerin, D., E. Charbonneau, L. Fadul-Pacheco, O. Soucy, and M. A. Wattiaux. 2017. Economic effect of reducing nitrogen and phosphorus mass balance on Wisconsin and Québec dairy farms. J. Dairy Sci. 100:8614-8629. https://doi.org/10.3168/jds.2016-11984.

Reynolds, C. K., and N. B. Kristensen. 2008. Nitrogen recycling through the gut and the nitrogen economy of ruminants: An asynchronous symbiosis. J. Anim. Sci. 86(E. Suppl.):E293-E305. https: //doi.org/10.2527/jas.2007-0475.

Spanghero, M., and Z. M. Kowalski. 1997. Critical analysis of N balance experiments with lactating cows. Livest. Prod. Sci. 52:113122. https://doi.org/10.1016/S0301-6226(97)00138-3.

Spek, J. W., J. Dijkstra, G. van Duinkerken, W. H. Hendriks, and A. Bannink. 2013. Prediction of urinary nitrogen and urinary urea nitrogen excretion by lactating dairy cattle in northwestern Europe and North America: A meta-analysis. J. Dairy Sci. 96:4310-4322. https://doi.org/10.3168/jds.2012-6265.

Sun, F., M. J. Aguerre, and M. A. Wattiaux. 2019. Starch and dextrose at 2 levels of rumen-degradable protein in iso-nitrogenous diets: Effects on lactation performance, ruminal measurements, methane emission, digestibility, and nitrogen balance of dairy cows. J. Dairy Sci. 102:1281-1293. https://doi.org/10.3168/jds.2018-15041.

Thoma, G., J. Popp, D. Nutter, D. Shonnard, R. Ulrich, M. Matlock, D. S. Kim, Z. Neiderman, N. Kemper, C. East, and F. Adom. 2013. Greenhouse gas emissions from milk production and consumption in the United States: A cradle-to-grave life cycle assessment circa 2008. Int. Dairy J. 31:S3-S14. https://doi.org/10.1016/ j.idairyj.2012.08.013.

Uddin, M. E. 2019. Evaluation of breed and diet on partial carbon footprint of milk produced in conventional system of Wisconsin. $\mathrm{PhD}$ dissertation, Department of Dairy Science, University of Wisconsin-Madison, Madison, WI.

Wattiaux, M. A., M. E. Uddin, P. Letelier, R. D. Jackson, and R. A. Larson. 2019. Invited review: Emission and mitigation of greenhouse gases from dairy farms: The cow, the manure, and the field. Appl. Anim. Sci. 35:238-254. https://doi.org/10.15232/aas.2018 $-01803$.

\section{ORCIDS}

M. E. Uddin ( https://orcid.org/0000-0002-8179-8944

O. I. Santana @ https://orcid.org/0000-0003-0268-2175

K. A. Weigel ( https://orcid.org/0000-0002-2391-6260

M. A. Wattiaux (ㄴ) https://orcid.org/0000-0001-8713-1641 